\title{
Quousque tandem: The Reception of a Catchphrase
}

\section{Introduction}

If ever a turn of phrase has captured the spirit of a man both in terms of his brilliance as an artist and of his importance as an historical actor, it is the rhetorical question with which Cicero opened his condemnation of Lucius Sergius Catilina in November of 63 BC: quousque tandem abutere, Catilina, patientia nostra ${ }^{1}$ This opening line has become synonymous with Cicero in the modern world, and has been appropriated and misappropriated by any number of figures attempting to enlist the force of classical antiquity's most celebrated orator to buttress an attack on a figure they hold to be overbearing, dangerous and tyrannical. As recently as November 2014, the United States senate was presented, to no little bemusement, with an attack on the President delivered by the junior Senator for Texas Ted Cruz, which began: "When, President Obama, do you mean to cease abusing our patience? How long is that madness of yours still to mock us? When is there to be an end to that unbridled audacity of yours, swaggering about as it does now?". 2

This aim of this short paper is to place Ted Cruz's use of this apophthegm in its classical context. Of the many, many sentences penned by Cicero, how did this one come to supersede the others as his most famous quotation? I shall

Note: As well as rendering much deserved thanks to the editors of this volume and the anonymous reviewers for their comments and encouragement, I would like to offer particular thanks to three groups of people. First, to Leiden University‘s Christoph Pieper, Bram van der Welden and Leanne Jansen, whose work on Ciceronian reception has informed my own approach in more ways than they may know. Secondly, to two former students of Oxford's Jesus College, Ed Bispham and Jenyth Evans - their patientia was much exercised in conversations on this topic. Thirdly, to British Airways, whose skilful handling of an emergency landing on the way home from the conference at which this paper was first delivered allowed it to appear in this written form.

1 Cic. Cat. 1.1. For an ancient interpretation of this line, see: Quint. 9.2.8.

2 This speech, delivered on the $20^{\text {th }}$ November 2014, was a response to President Obama's planned Executive Order on Immigration. Prior to this, Ted Cruz had gained attention by supplementing an attack on the President with another famous quotation, reciting Dr Seuss' Green Eggs and Ham as part of a 21-hour marathon speech attacking the Affordable Care Act ("Obamacare") in 2013.

Ә OpenAccess. ( 2022 Andrew J. Sillett, published by De Gruyter. (cc)BB the Creative Commons Attribution 4.0 International License. https://doi.org/10.1515/9783110748703-016 
argue that this is no recent phenomenon, and that the special attention received by this phrase was apparent even in antiquity.

I will begin this study with a brief investigation of the extent to which these words gained notoriety during Cicero's own lifetime (relying both on Cicero's own speeches and on what can be recovered of those delivered by his opponents). With this foundation having been laid, I will move on to discuss the varied uses to which it was put after Cicero's death.

Although there is already a far from insignificant bibliography relating to a few of these instances of Ciceronian reception, there is as yet no systematic study of how these individual moments of intertextuality relate to and build upon each other. ${ }^{3}$ It is my belief that by studying these items together we can shed a light on the complexity of Cicero's Nachleben and trace how different facets of his reception (hero, villain, politician, wordsmith) either waxed and waned or, perhaps more profitably, how they blended into and reinforced one another, and how they changed over time.

\section{Contemporary Resonances}

As Mary Beard noted in an article from a 2013 collection of popular articles on the resonances of the Greek and Roman world in contemporary culture, public figures from Congolese dictators to French philosophers have found themselves at one time or another pursued by the ringing denunciation quousque tandem abutere patientia nostra? ${ }^{4}$ Far from being just a shorthand for Cicero's four Catilinarian speeches and for the entirety of Cicero's campaign against Catiline, these words have come to be attached to any attack on a figure perceived to have outraged the norms and customs of decent society.

This practice began rather earlier than has often been appreciated. Sometime in the early summer of $61 \mathrm{BC}$ Cicero wrote a letter to Atticus describing the aftermath of his decision to give evidence against Clodius in the latter's trial de incestu for invading the rites of the Bona Dea. ${ }^{5}$ Clodius, still piqued by Cicero's decision to shatter the alibi he had planned on using in his trial, did not take kindly to being assailed by him once again, this time in the Curia as Cicero denounced the corruption of the jury which had acquitted Clodius, and to

3 Skard 1956, Syme 2002, Renehan 1976, Innes 1977, Seager 1977, Malcolm 1979, Oakley 1997, Wiseman 1979, Nousek 2010, Sillett 2015.

4 Beard 2013, 85-86.

5 Cic. Att. 1.16. For a recent interpretation of this letter, see Lintott 2008, 6-8. For the Bona Dea scandal, see Moreau 1982, Epstein 1986, Tatum 1990, Lintott 2008,154-159. 
hold forth more generally on the guilt and miscreancy of the man himself. Cicero relates to Atticus the altercatio which followed. The verbal joust is worth repeating in full, and the section relevant to the interests of this paper has been underlined (quousque hunc regem feremus?):

\begin{abstract}
Surgit pulchellus puer, obicit mihi me ad Baias fuisse. Falsum, sed tamen. "Quid? hoc simile est - inquam - quasi in operto dicas fuisse?" "Quid - inquit - homini Arpinati cum aquis calidis?" "Narra - inquam - patrono tuo, qui Arpinatis aquas concupivit” (nosti enim Mari<a>nas). "Quousque - inquit - hunc regem feremus?" "Regem appellas - inquam - cum Rex tui mentionem nullam fecerit?" - ille autem Regis hereditatem spe devorarat. "Domum - inquit - emisti". "Putes - inquam - dicere 'iudices emisti”. "Iuranti - inquit - tibi non crediderunt". "Mihi vero - inquam - xxv iudices crediderunt, xxxI, quoniam nummos ante acceperunt, tibi nihil crediderunt”. magnis clamoribus adflictus conticuit et concidit. ${ }^{6}$

Our little Beauty gets on his feet and accuses me of having been at Baiae - not true, but anyhow, "Well", I reply, "is that like saying I intruded on the Mysteries?" "What business has an Arpinum man with the warm springs?" "Tell that to your counsel”, I retorted; "he was keen enough to get certain of them that belonged to an Arpinum man" (you know Marius' place of course). "How long”, cried he, "are we going to put up with this king?" "You talk about kings”, I answered, “when Rex didn't have a word to say about you?” (he had hoped to have the squandering of Rex's money). "So you've bought a house", said he. I rejoined, "One might think he was saying that I had bought a jury". "They didn"t credit you on oath". "On the contrary, 25 jurymen gave me credit and 31 gave you none - they got their money in advance!" The roars of applause were too much for him and he collapsed into silence (Trans. Shackleton Bailey 1999).
\end{abstract}

This may be a fairly simple joke, one which echoes back Cicero's own rhetoric to criticize his recent elevation to the summit of Roman political life and his concomitant influence on affairs which his enemies felt bordered on the tyrannical. The joke is an effective one, and good evidence that it did not take long for the rhetorical question with which Cicero began his first Catilinarian to gain a life of its own. ${ }^{7}$

6 Cic. Att. 1.16.10. Cicero's neat rejoinder remarks on the fact that Clodius was no authority on the subject of kings since he had recently been snubbed in the will of a man named Rex - a pun Julius Caesar would later make his own: Suet. Iul. 79.2. For this text as an oratorical fragment, see Malaspina 1997.

7 Indeed, as Dominic Berry has suggested to me per litteras, since the publication of the first Catilinarian can only be securely dated to $60 \mathrm{BC}$, then this letter is the earliest surviving attestation of Cicero's use of that speech's famous opening line. Clodius' ability to quote this memorable opening line to a senatorial audience does not, of course, prove one way or the other whether Cicero had published his Catilinarian speeches at this point. For the vexed question of the Catilinarians' publication, see Kennedy 1972, 176-178. More recently, see McDermott 
This example is exceptionally clear, but it is not the only quotation delivered by one of Cicero's contemporaries during his lifetime. In 54 BC, Cicero's younger brother Quintus began a period of service as a legate assisting Julius Caesar in his Gallic campaign. Although he distinguished himself in his first year, weathering a siege while in winter quarters among the Nervii, and receiving warm words in Caesar's commentary for that year, things took a turn for the worse the next summer. ${ }^{8}$

In $53 \mathrm{BC}$, Quintus, no doubt on the basis of his meritorious service the previous year, was entrusted with overseeing the camp at Aduatuca while Caesar attacked the territory of the Eburones. Although under strict instructions to keep the soldiers safely inside the fortifications, Caesar relates in his commentary for that year that the troops under Quintus' command did not have too much trouble convincing him to let them out of their confinement to forage for supplies (Caes. Gall. 6.36):

Cicero, qui omnes superiores dies praeceptis Caesaris cum summa diligentia milites in castris continuisset ac ne calonem quidem quemquam extra munitionem egredi passus esset, septimo die diffidens de numero dierum Caesarem fidem servaturum, quod longius progressum audiebat, neque ulla de reditu eius fama adferebatur, simul eorum permotus vocibus, qui illius patientiam paene obsessionem appellabant, siquidem ex castris egredi non liceret, nullum eiusmodi casum exspectans, quo novem oppositis legionibus maximoque equitatu dispersis ac paene deletis hostibus in milibus passuum tribus offendi posset, quinque cohortes frumentatum in proximas segetes mittit, quas inter et castra unus omnino collis intererat.

For all the previous days Cicero, in obedience to Caesar's instructions, had most carefully confined his troops to camp, allowing not even a single camp-follower to pass beyond the entrenchment. On the seventh day he did not feel sure that Caesar would keep his word as touching the number of days, as he heard that he had advanced farther, and no report about his return was brought in. At the same time, he was influenced by the remarks of those who called his patience almost a siege, since no leave to pass out of camp was given; and he did not anticipate any turn of fortune such as, with nine legions and a very large force of cavalry to confront a scattered and almost obliterated enemy, could cause disaster within the distance of three miles. He therefore sent five cohorts to get corn in the nearest fields, between which and the camp but a single hill interposed (Trans. Edwards 1917).

1972, Stroh 1975, 51 n.90, Stroh 1983, 41-42, Classen 1985, 3- 6, Vasaly 1993, 8-10, Batstone 1994, 213-214, Berry 2020, 56-82.

8 For Quintus' bravery in 55 BC, see: Caes. Gall. 5.38-52. For the motivations of both Ciceros for sending Quintus to serve with Julius Caesar, see Wiseman 1966. 
The aftermath of Quintus' decision to yield to the soldier's demand was devastating. As soon as the troops were freed from the safety of their fortifications, they were fallen upon by marauding Sugambri, and were only saved from destruction by Caesar's swift and fortuitous return to camp.

Although the reference to the first Catilinarian here is not anything like as clear as Clodius' jibe to Marcus Cicero, it is not difficult to discern Julius Caesar's hint at the precise phrase with which the soldiers needled Quintus into action: illius patientiam paene obsessionem appellabant ("they called his patience almost a siege"). It is no great a leap of the imagination to reconstruct the oratio recta of the soldiers' taunts, assailing Quintus Tullius Cicero with the words of his more famous brother: quousque tandem abutere, Cicero, patientia nostra?

As the fame of the opening words of his first Catilinarian became ever more cemented in Roman popular consciousness, it should be no surprise to find Cicero himself returning to them in his later oratory, and where better to do so than in his Philippics? Where better than in a series of speeches in which Cicero returned to frontline politics to confront a villain and a threat to the Republic, one whose infamy was often interpreted by Cicero as that of the true inheritor of Catiline's dagger?'

At the beginning of the third Philippic, a speech which (in spite of its modern title $^{10}$ ) was the opening salvo Cicero fired in his war against Mark Antony, we find a self-conscious return to the chilly November of his consulship (Phil. 3.3):

Quo enim usque tantum bellum, tam crudele, tam nefarium privatis consiliis propulsabitur?

So, how long will a war of such magnitude, a cruel and wicked war, be beaten back by private initiatives? (Trans. Shackleton Bailey 2010)

The echo is admittedly faint here, lacking as it does any reference to the verb abutor or the noun patientia, and with the tandem only present in the similarsounding appearance of the word tantum after the opening quousque. The context of the third Philippic nevertheless aids this line of interpretation. The central thesis of the second Philippic, the manifesto which precedes this speech in its published form, is that since Cicero was the man who put down Catiline's revo-

9 Cic. Phil. 4.15; 8.15; 13.22; 14.14.

10 The first Philippic being a rather emollient plea for Antony to turn back from his journey towards despotism, and the second Philippic being a pamphlet published considerably after its dramatic date. On the corpus and the titles of the Philippics, see Manuwald 2007. 
lution, he is the ideal figure to lead the fight against Mark Antony. ${ }^{11}$ How better to underline this argument than to call to mind the opening line of the attack which pushed him, for a while at least, to the front of Rome's political elite?

\section{Sallust's Inversions}

The death of Cicero, just shy of a year after he delivered the third Philippic, marks a turning point in the reception of this phrase. No longer could it be deployed in support of Cicero's current political position, nor could it be turned against him as part of an attack on his standing within the state. It did not, however, render the phrase either obscure or obsolete. Leaping forward a few decades or so from Cicero's death, we find the first post-mortem proof of the line's growing canonical status. In Seneca the Elder's discussion of a Suasoria on the subject of Cicero's fictional final reckoning with Mark Antony, he turns to the subject of Cicero's bibulous son (Sen. suas. 7.14):

Erat autem, etiam ubi pietas non exigeret, scordalus. Hybreae, disertissimi viri, filio male apud se causam agenti ait: $\dot{\eta} \mu \varepsilon \tilde{\varsigma}$ oũv $\pi \alpha \tau \varepsilon \dot{\rho} \omega v$; et, cum in quadam postulatione Hybreas patris sui totum locum ad litteram omnibus agnoscentibus diceret, "age - inquit - non putas me didicisse patris mei: quousque tandem abutere, Catilina, patientia nostra?”

Marcus, however, was quarrelsome even when piety did not demand it. To the son of the eloquent Hybreas, who was making a mess of a case he was conducting before him, he said: "Do we, then, claim to be better than our fathers?" And when in some application or other Hybreas spoke a whole passage from his father's writings to the letter and everyone recognised it, Marcus said: “Come now, do you think I haven’t got off by heart my father's: How much longer, Catiline, will you abuse our patience?” (Trans. Winterbottom 1974).

In a manner somewhat reminiscent of Clodius' redeployment of the line, Marcus Junior uses the quotation as part of a joke: portraying an audience bored by a speaker's repeated plagiarism as the Roman senate witnessing Catiline's stubborn refusal to hide his face after Cicero's denunciations. The internal logic of the bon mot, however, is useful to the student of Ciceronian reception: it does not just take as read the idea that the opening words of the first Catilinarian would be immediately recognizable to a general audience as any old famous piece of oratory, it depends upon them recognizing it as Cicero's own.

11 Catiline bookends the second Philippic, appearing as he does in both the first and penultimate chapters: Cic. Phil. 2.1, 2.118. 
Given, then, that the salience of this phrase outlived its author, it would be strange indeed if it were to be absent from an historical monograph written in the aftermath of Cicero's death and dedicated to the subject of his famous oratorical triumph over Catiline. Although Sallust's Catiline finds a way to shock the reader on almost every page, it does not surprise on this front. In the middle of the work's very first speech, we encounter the familiar rallying cry (Sall. Cat. 20.9):

\begin{abstract}
"Quae quousque tandem patiemini, o fortissumi viri? nonne emori per virtutem praestat quam vitam miseram atque inhonestam, ubi alienae superbiae ludibrio fueris, per dedecus amittere?"

"How much longer still will you put up with this, o bravest men? Is it not better to die valiantly, than ignominiously to lose a wretched, inglorious life in which you end up being an object of derision in the eyes of some haughty person?” (Trans. Rolfe 2013)
\end{abstract}

This is a neat piece of variatio upon the original Ciceronian line: the phrase itself loses its place as a speech's opening note; ${ }^{12}$ the notorious first couple of words have been bumped back one place behind the object, which has been thrown forward to the front of the sentence and become a relative pronoun; the vocative has taken the object's place at the sentence's end and has been replaced with another Ciceronian formulation from the first Catilinarian; ${ }^{13}$ while the sense of the original patientia is taken over by the main verb of the sentence (a cognate form which also appears frequently in the Catilinarians). ${ }^{14}$

These minor and artful modifications pale into insignificance, however, next to the biggest alteration of all: the fact that Cicero's exordium has been transferred into the mouth of his foe. Much as Clodius had mocked Cicero by stealing these words from him in $61 \mathrm{BC}$, so Sallust transfers them to Catiline in his history. It is far from easy to know how to interpret this transposition, and it has been the object of some (but not much) scholarly debate. Sir Ronald Syme provides a good starting point for the debate. Discussing the passage in his Sallust, he recognizes Catiline's appropriation of the line, but does not think much of its importance. As he idiosyncratically puts it: "if that is malice, it is not very noxious". ${ }^{15}$

12 Other plays on the phrase retain it in its opening position: we can see this in Livy below, but it is also apparent in Tacitus' two uses of the phrase and its usage in Apuleius: Tac. Ann. 1.13.28; Apul. Met. 3.27.

13 Cic. Cat. 1.21 (referring to his own supporters outside the temple where he has convened the Senate): Honestissimi atque optimi viri, ceterique fortissimi cives.

14 Patior appears in its various forms nine times in the course of the four Catilinarians.

15 Syme 2002, 106. 
Renehan provides the antithesis to this view, arguing that, noxious or not, the parody shows a disrespectful attitude to Cicero on Sallust's part: he finds an analogous situation in which Sallust acted similarly with Cato or Caesar unthinkable. Summing up this stance (in what is presumably his own parody of Syme's style): "Here the Roman Thucydides laughed". ${ }^{16}$

The assessment that this is primarily an opportunity for Sallust to demonstrate his sense of humour is one shared by Robin Seager. ${ }^{17}$

Writing in the same year as Seager, Doreen Innes provides a rebuttal to Renehan's thesis. On her reading, Sallust is not attempting to parody Cicero by putting his words in Catiline's mouth, but rather he is highlighting the latter's wickedness. Just as Catiline misuses and perverts the meaning of words like virtus fidesque at the start of his speech, his appropriation of the words of the first Catilinarian shows that he can even take the words which sealed his fate and forge them into an exhortation to his caterva of scoundrels. This is, then, really a subtle tribute to Cicero and the original valour of his speech. ${ }^{18}$ One might push this idea further and argue that Catiline's ability to talk like Cicero is evidence of the fact that he had all the qualities necessary to be an outstanding citizen, but chose to misuse them. His Ciceronian rhetoric, on this reading, serves as a reminder of the path not taken. ${ }^{19}$

A more radical approach is taken by D. A. Malcolm, who interprets the appearance of these words in Catiline's speech as a nod to Catiline himself being the originator of this famous phrase. ${ }^{20}$ In this provocative reading, Cicero's rhetorical genius lay in throwing Catiline's own words back in his face. By extension, Sallust is merely returning the phrase to its rightful inventor. Intriguing suggestion though this may be, it is unfortunately impossible to produce any evidence to back it up, and so it must remain just a suggestion. Moreover, we should be suspicious that this interpretation appears nowhere in ancient scholarship on the first Catilinarian. If it was widely understood that this was the key to interpreting this famous line, then it is difficult to believe that Quintilian, who

16 Renehan 1976, 100.

17 Seager 1977, 383. Although there is little material directly concerning Sallust, for a treatment of wit in Roman historiography, see Plass 1988.

18 Innes 1977, 468. She goes on to compare this with Sallust's other parody of the line at Sall. hist. 1.77.15, with Philippus being set up as a proto-Cicero against Lepidus, who is being subtly compared to Catiline through this allusion.

19 I owe this last point to Rhiannon Ash.

20 Malcolm 1979, 219-20; cf. Skard 1956, 108, Berry 2020, 92-93. 
discusses it twice, would have missed so important a point in his own studies of these words. ${ }^{21}$

This survey of the divergent (and even opposite) responses that have been generated by Sallust's redeployment of Cicero's phrase is a fine demonstration of just how potent these words both were and are. There is no easy answer to the question of what Sallust thought he was doing by placing Cicero's words in Catiline's mouth, and we may simply have to accept that this text can simultaneously mock and praise Cicero at the same time. ${ }^{22}$ The prejudices the reader brings to Catiline's speech will ultimately be the deciding factor in working out what it means for him to take over the opening words of the first Catilinarian.

Sallust's relationship with this phrase is not, however, confined to this single moment in his first monograph. Near the start of his Histories we find it rearing its head again, this time in the voice of Lucius Marcius Philippus, consul of 91 $\mathrm{BC}$, who set himself in opposition to the anti-Sullan martial manoeuvrings of Marcus Aemilius Lepidus, father of the Triumvir of the same name. As Philippus assails the assembled senators for allowing Lepidus to gather strength through their inertia, he asks them (Sall. hist. 1.77.5):

\footnotetext{
"Vos autem, patres conscripti, quousque cunctando rem publicam intutam patiemini et verbis arma temptabitis?"

"But you, Members of the senate, for how long will you suffer the nation to be defenceless by your hesitation, will you combat arms with words?' (Trans. Ramsey 2015)
}

This reproduction of Cicero's phrase is indebted both to its original appearance at the head of the first Catilinarian and to Sallust's own reformulation of it his Catiline. ${ }^{23}$ The simplest interpretation of Sallust's decision to repeat the borrowing here is that he wishes to highlight the similarities between the revolts of two swaggering patricians against the serried forces of Sulla's orphaned nobility.

Another possibility suggests itself, however, and that would be to suppose that a much more recent comparison is being essayed. Close parallels though there may be between Lepidus' revolt and that of Catiline, one does not have to strain to see a further Antonian parallel in Sallust's portrayal of a renegade Roman magistrate in command of an army in northern Italy being buffeted by

21 Quintilian directly quotes the line twice (4.1.69, 9.2.7-8) and never even so much as hints that the words were originally spoken by Catiline. It is, of course, possible that the true origin of the line was lost in the imperial period. This, however, prompts the question where Sallust got his information from, and how it passed by Quintilian.

22 Cf. Hinds 1998, XI.

23 McGushin 1992, ad loc. 
the oratorical onslaught whipped up in Rome by an aging consular keen to stir the senate into action against his foe, and personally fond of doing so with reference to the opening line of the first Catilinarian.

Sallust is, of course, well-known as one of Cicero's most attentive readers, and it is hardly surprising to find him taking part in the process of redeploying a well-known piece of Ciceronian oratory in order to draw parallels between different moments in Roman history. What is remarkable, though, is just how little time had passed between Cicero violently becoming part of the furniture of the Roman past and the back catalogue of his oratorical greatest hits becoming the raw material of Roman history. Even more remarkable is that of all the speeches and treatises that Cicero produced in his lifetime, a single line from a single speech became, for Sallust and his readers, at least, the perfect encapsulation of Cicero's life, career and political outlook. The intensity of Sallust's relationship with Cicero was, however, far from typical. ${ }^{24}$ It remains to be seen how far this was true for other writers of the imperial period. To Sallust's successors we must now turn.

\section{Ab Urbe Condita}

As it happens, we do not have to look very far to find the next Roman author interested in exploiting the opening of the first Catilinarian to drive their work along. The spectre of Cicero is raised time and again in the text of Livy's history. Stephen Oakley makes a strong case for reading the entirety of chapters 14-21 of the sixth book of Livy's history on the rise and fall of Marcus Manlius Capitolinus as inextricably bound up with the rise and fall Lucius Sergius Catilina, another popularis patrician whose fall was as precipitous as his rise. ${ }^{25}$

Livy's attempts to create a parallel between these two men can be seen in the late-night conspiratorial meetings they hold in aristocratic houses and the role played by injured dignitas in spurring on their plots. The fact, however, that Livy is not simply drawing a parallel with Catiline, but rather with a Catiline who harks back to both Cicero and Sallust, is made clear in the speech to the plebs urbana that Livy composes for Manlius (Liv. 6.18.5):

24 The belief that Cicero and Sallust sat at loggerheads with each other was popular enough to form the basis of an entire declamatory tradition, recently discussed by Keeline 2018, 147-195; La Bua 2019, 102-106.

25 Oakley 1997, 481-484. For Manlius Capitolinus, see Liv. 5.47; 6.11; 6.14-20; Dion. Hal. Ant. Rom. 13.7.3-8.2; 14.4; Plut. Cam. 27, 36; Dio Cass. fr. 25.10, 26.1-3; Diod. Sic. 14.116.5 -7. This similarity was also noted by Wiseman 1979, 46-47. 
His simul inflatus exacerbatusque iam per se accensos incitabat plebis animos: "Quousque tandem ignorabitis vires vestras, quas natura ne beluas quidem ignorare voluit?”

Self-satisfied and at the same time embittered by such thoughts, he set to work on rousing the already inflamed passions of the plebs: "So how long are you going to remain ignorant of your strength?' he asked them. 'That is something that nature has decided even wild animals should not be unaware of!” (Trans. Yardley 2013).

The connection itself is relatively easy to spot but understanding how this link should be interpreted is a more difficult task. ${ }^{26}$ One of the finer points Livy accomplishes with this reference is to flag up the duality of Manlius Capitolinus. While the combination of the popularis thrust of his speech and the background of conspiratorial activity that preceded it allows Livy to align Manlius with Catiline, he complicates and possibly undermines this simple picture by having him echo Cicero's famous words.

On one level, this reference to a line which had become common currency before Livy first picked up his pen is simply another indication that the historian wants his readers to see the Manlian affair as a fourth-century Catilinarian crisis. ${ }^{27}$ If we look closer, however, we see Livy doing something rather more complicated. After all, on one level it is perfectly fitting that Manlius Capitolinus should sound like Cicero in his attempt to crush Catiline's attempt to burn down the city of Rome. As Capitolinus himself reminds his audience in a speech delivered just a few chapters earlier (Liv. 6.16.2):

Arreptus a viatore "Iuppiter - inquit - optime maxime Iunoque regina ac Minerva ceterique di deaeque, qui Capitolium arcemque incolitis, sicine vestrum militem ac praesidem sinitis vexari ab inimicis? haec dextra, qua Gallos fudi a delubris vestris, iam in vinclis et catenis erit?"

Seized by the attendant, Manlius declared: "Best and Greatest Jupiter, Queen Juno and Minerva, and all the other gods and goddesses that reside in the Capitol and citadel, are you allowing your soldier and guardian to be persecuted by his enemies like this? This is the right hand with which I chased the Gauls off from your shrines - is it now going to be in bonds and chains?” (Trans. Yardley 2013).

26 This has been commented upon by: Skard 1956, 108; Seager 1977, 383; Wiseman 1979, 47; Malcolm 1979, 219; Nousek 2010, 158-159; Berry 2020, 199. For a dismissal of this point on the grounds that the use of only the first two words of the phrase is not enough to signal Cicero, see: Renehan 1976, 100.

27 The theory that the phrase quousque tandem was first used by Catiline himself and then repeated by Cicero, an idea found in Malcolm 1979, would certainly support this view. 
If we focus on this section of Manlius' speech, a section which precedes his quotation of the first Catilinarian, then it becomes difficult to avoid seeing Livy's character as far from a simple villain. As well as a figure put to death for conspiring against Rome, Manlius was a hero who had saved the city from destruction during the Gallic occupation described in the previous book of Livy's history. Manlius, then, has equal claim to both the role of Catilinarian villain and that of Ciceronian hero. He is equally at home conspiring toward the destruction of the res publica and bewailing his fate at the hands of an ungrateful city that he personally saved from destruction.

It may not be surprising at this point to see that Livy achieves this effect with reference to the opening line of the first Catilinarian. The level of sophistication inherent in the uses of these words also deserves recognition. Livy does not simply deploy this line in order to set up a facile comparison between, say, an eloquent character from Rome's past and her most celebrated orator. Sallust's previous interaction with these words has barnacled the line with a deeper meaning which Livy is able exploit in his history. Cicero's well-known quotation is kept in reserve by Livy until a moment presents itself when he can exploit the latent potential of its Ciceronian and Sallustian heritage in order to expose the possibility that Roman heroism and Roman villainy can reside within the same breast.

\section{Further Imperial Receptions}

We have so far seen that Cicero's Catilinarian catchphrase quickly began to take on a life of its own. It ceased to be a simple short-hand signifier of Cicero's first Catilinarian oration (as it was used by both himself and Clodius during his lifetime), and it was not just a common way of makingreference to Cicero's oratorical prowess or broader rhetorical corpus (as it was used by his son in the anecdote preserved by Seneca the Elder). Instead we have seen a desire among two historians of the early imperial period to exploit the phrase's origin in the murkiness of the Catilinarian crisis and so use it to highlight the moral ambivalence of its author.

This is not to say that the sophisticated treatments of the phrase by Livy and Sallust removed it from the world of everyday quotation. A letter from Pliny the Younger to Octavius, dated to late $97 \mathrm{AD}$ and expressing a desire to see some of the verse his friend has been composing, begins as follows: 


\begin{abstract}
Hominem te patientem vel potius durum ac paene crudelem, qui tam insignes libros tam diu teneas! Quousque et tibi et nobis invidebis, tibi maxima laude, nobis voluptate? ${ }^{28}$

What an easy-going fellow you are, or rather a hard-hearted, virtually cruel one, since you cling to your outstanding works for so long! For how long will you bear a grudge against yourself and against me? (Trans. Walsh 2006)
\end{abstract}

Although lacking some elements of the original, the confluence of quousque, $p a-$ tiens and the first-person plural pronoun makes it hard to avoid the feeling that Pliny is playfully comparing the tolerance he is exercising in the face of his friend's refusal to share any drafts of his poetry with Cicero's exhausted patience in the face of Catiline's shameless appearance in the temple of Jupiter Stator more than 150 years earlier. ${ }^{29}$

The passage of time, however, did not lead to a situation where all references to this phrase were essentially employed as light-hearted hyperbole or showy displays of learning. The first book of Tacitus' Annales proffers two examples of Cicero's catchphrase being deployed with no little sophistication. As news of Augustus' death in $14 \mathrm{AD}$ spread through the empire, Tacitus reports that the troops stationed on the Rhine and in the province of Pannonia decided to use the uncertainty of the times to advance the case for a comprehensive pay review. The presence of the new emperor's son Drusus bearing assurances of fair treatment did little to cool the ardour of the Pannonian legions, who, after some fraught negotiations, settled upon the plan of securing the emperor's son as a hostage to their demands. The sudden onset of a lunar eclipse, however, led to a large number of the mutineers losing their nerve and offered Drusus an opportunity to turn his fortunes around (Tac. ann. 1.28.4-6):

Utendum inclinatione ea Caesar et quae casus obtulerat in sapientiam vertenda ratus circumiri tentoria iubet; accitur centurio Clemens et si alii bonis artibus grati in vulgus. Hi vigiliis, stationibus, custodiis portarum se inserunt, spem offerunt, metum intendunt. "quousque filium imperatoris obsidebimus?”.

Feeling he should capitalize on the turn of events and make prudent use of what chance had offered him, Drusus ordered the rounds made of the tents, and the centurion Clemens was summoned, along with any others whose qualities made them favourites of the mob. These men infiltrated the watches, the guard posts and the sentries at the gates, offering them hope and working on their fears. 'How long are we going to keep the emperor's son under siege?' they would say (Trans. Yardley 2008).

28 Plin. ep. 2.10.1-2.

29 Whitton 2013, ad loc. 
The similarity between this passage and the opening of Cicero's first Catilinarian is, admittedly, slight, limited as it is to the famous opening word. It is, however, a vanishingly rare word in Tacitus, and it is hard to believe that the author of the Dialogus would be unaware of the heritage of opening a piece of direct speech with this particular question word. How better, after all, to convey the sense of an enterprising member of Drusus' staff deciding that his youthful training in rhetoric will be the key to turning the tide of this crisis?

The best supporting evidence for thle idea that we should read Cicero into the centurion's speech, however, is the fact that the only other instance of Tacitus using the word quousque is to be found only a few chapters before this, in a far more openly Ciceronian manner. Tacitus' account of the accession of Tiberius to sole rule over the empire emphasises the contrast between his personal unwillingness to step into his late stepfather's shoes and the senate's insistence that he do so without hesitation. As the individual senators despair of achieving their desired result through obsequious flattery alone, Tacitus presents some of the senior consulars adopting a more confrontational manner, thus incurring the Princeps-to-be's displeasure (Tac. ann. 1.13.4):

Etiam Q. Haterius et Mamercus Scaurus suspicacem animum perstrinxere, Haterius cum dixisset "quousque patieris, Caesar, non adesse caput rei publicae?"

Quintus Haterius and Mamercus Scaurus also provoked his suspicious nature, Haterius by saying 'How long, Caesar, are you going to let the republic be without a head?' (Trans. Yardley 2008).

In addition to the prominent placement of the quousque question, Tacitus provides us with a second marker of this question's Ciceronian origin in his use of patieris, a verbal link back to the original patientia favoured by Sallust in both of his references to the first Catilinarian.

This cross-reference with the first Catilinarian is an opposite one, and one which provides an early hint as to how Tacitus will present both the institution of the senate and its individual senators as his work progresses. By creating an unmistakable verbal echo of Cicero's speech in Haterius' question, Tacitus highlights the chasm that yawns between the vibrant, vital institution the senate was in Cicero's heyday, and the craven, sycophantic body it had developed into in the imperial period. The opening couple of words in Haterius' question designate him as the Cicero of the dawning Tiberian age, a man who can represent the firm-minded independence of that august body; what follows merely confirms what we should expect - that his priority is transferring as much power as possible away from the senate and towards the new emperor. 
Tacitus' quotation of the first Catilinarian presents a different perspective from that found in Sallust and Livy. While those historians used these words to emphasise the moral ambiguity of their speakers, Tacitus employs them in a manner which lionizes Cicero at the expense of his counterpart. The specific choice to do this via the first Catilinarian is not, however, simply a shorthand way of bringing Cicero into play. The parallel of the opening days of the Catilinarian crisis exposes the nature of the debate taking place in 14 AD. Augustus' exit from the stage and Tiberius' unwilling arrival presents a moment of crisis for Rome every bit as existential as Catiline's alleged plotting. Tacitus' insertion of Cicero's quousque both emphasises the gravity of the situation being narrated and highlights the fact that the reader can no longer expect the senate to furnish Rome with a redeemer.

\section{Conclusion}

Although the starting point of a paper on the reception of the opening line of Cicero's first Catilinarian is obvious enough, establishing where to finish it is rather more of a challenge. The volume of which this forms a part is a contribution to the recent flurry of activity that has blown up around Ciceronian reception. I would like, however, to look back to an article on the subject that preceded this spate of activity and set its direction of travel. ${ }^{30}$ Bob Kaster's 1998 article "Becoming CICERO" lays out the thought-provoking thesis that the story of Cicero's reception is one of kitsch-ification. ${ }^{31}$ As the memory of the real Cicero receded into the past, a burlesque caricature of him came to dominate the mind of antiquity, a figure Kaster christens "CICERO". I would like to end this piece with one last, unmistakable nod in the direction of Cicero's catchphrase which captures Kaster's theorized simplification of Cicero/CICERO.

In the course of the epic span of eleven books, Apuleius' Metamorphoses tells the tale of a young man, Lucius, who is surprised to find that his interference with a group of witches has left him transformed into an ass and forced to undergo a series of impish adventures in order to regain his original form. Early on in his journey, Lucius gains a taste of the indignities which will be visited upon his new body (Apul. met. 3.27):

30 See recently: Keeline 2018, LaBua 2019, Sillett 2015, and the forthcoming publications from Christoph Pieper's "Mediated Cicero" project based at the University of Leiden.

31 Kaster 1998. 
Denique adgnito salutari praesidio pronus spei, quantum extensis prioribus pedibus adniti poteram insurgo valide, et cervice prolixa nimiumque porrectis labiis, quanto maxime nisu poteram corollas adpetebam. Quod me pessima scilicet sorte conantem servulus meus, cui semper equi cura mandata fuerat, repente conspiciens, indignatus exurgit, et "Quousque tandem - inquit - cantherium patiemur istum paulo ante cibariis iumentorum, nunc etiam simulacris deorum infestum? Quin iam ego istum sacrilegum debilem claudumque reddam".

So in an ecstasy of hope on identifying this assurance of salvation, I stretched out my forelegs and with all the strength I could muster, I rose energetically on my hind legs. I craned my neck forward, and pushed out my lips to their full extent, making every possible effort to reach the garlands. My attempt was frustrated by what seemed to be the worst of luck: my own dear servant, who always had the task of looking after my horse, suddenly saw what was going on, and jumped up in a rage. "For how long' - he cried - are we to endure this clapped-out beast? A minute ago his target was the animals' rations, and now he is attacking even the statues of deities! See if I don't maim and lame this sacrilegious brute!” (Trans. Walsh 1994)

This quotation of the first Catilinarian is as clear as one could wish for here: the quousque is followed by the tandem and, as we have seen numerous times, the patientia is present in a form of the verb patior. Where the previous examples that have been studied above, however, show a degree of sophistication in their engagement with the circumstances of the line's original delivery, Apuleius' quotation suggests no understanding of the quotation beyond the basic fact that it is a famous phrase. ${ }^{32}$

It is far from inconceivable, of course, that the best explanation for the difference in quality between Apuleius' quotation and those discussed above can be found in their respective genres - a work of historiography is far more likely to squeeze a great deal of meaning out of a piece of Cicero than a Roman novel is. It is, however, hard to avoid the conclusion that this picture fits very well with Kaster's thesis of a gradual decline in the subtlety of Cicero's reception in classical antiquity.

How far, then, should this chapter proceed? There is, of course, much more to be written on the reception of Cicero's famous phrase in Late Antiquity, in the Medieval period and down to the present day. ${ }^{33}$ But I will not abuse your patience any further on these pages.

32 On Apuleius' use of this Ciceronian phrase, see Tatum 2006; La Bua 2013.

33 Berry 2020, 210-213 (cf. 61-64). 